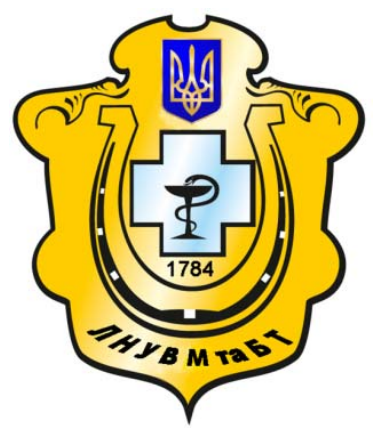

Науковий вісник Львівського національного університету ветеринарної медицини та біотехнологій імені С.3. Гжицького

Scientific Messenger of Lviv National University of Veterinary Medicine and Biotechnologies named after S.Z. Gzhytskyj

doi:10.15421/nvlvet7017

ISSN 2413-5550 print

ISSN 2518-1327 online

$\underline{\text { http://nvlvet.com.ua/ }}$

УДК: 616.091. 615.9:54

\title{
Патоморфологічні зміни за спонтанного отрусння голубів діазиноном
}

\author{
P.С. Данкович, В.В. Туманов \\ dancor1802@i.ua
}

\begin{abstract}
Львівський національний університет ветеринарної медицини та біотехнологій імені С.3. Гжсицького,
\end{abstract} вул. Пекарська 50, м. Львів, 79010, Украӥна

\begin{abstract}
Фосфорорганічні пестициди, у тому числі діазинон, досить часто застосовують для несанкиіонованого отруєння диких або свійських птахів. Загибель значної кількості тварин нерідко стає предметом розслідування у цивільних або кримінальних справах. Для об'єктивного встановлення діагнозу у таких випадках необхідно провести комплексне патологоанатомічне та хіміко-токсикологічне дослідження. У статті описані структурні зміни, які розвиваються в органах травлення, сериево-судинної системи, дихання, сечовиділення, икірі та центральній нервовій системі за спонтанного отруєння голубів діазиноном. Під час проведеного патолого-анатомічного дослідження виявили виражені дисииркуляторні прочеси: застійну гіперемію (особливо у судинах шкіри в ділянці шиї та вола), а також у внутрішніх органах, стази, периваскулярні набряки та крововиливи. Також реєстрували альтеративні зміни (переважно білкову дистрофію та некрози) гепатоцитів, кардіоміџитів, нефроцитів та нейронів головного мозку. Виявлені зміни свідчать про розвиток незворотніх альтеративних процесів у паренхіматозних елементах печінки, нирок, міокарду та головного мозку. Під час розтину відбирали матеріал (кормові маси з вола) для проведення хіміко-токсикологічного дослідження. За проведення дослідження екстракту з відібраного вмісту вола птииі методом тонкомарової хроматографії на папері з проявленням йодвісмутовим реактивом отримано якісну позитивну реакиію щодо сполуки діазинон.
\end{abstract}

Ключові слова: фосфорорганічні сполуки, діазинон, пестициди, отруєння, голуб сизий, патоморфологія, застійна гіперемія, вакуольна дистрофія, некроз.

\section{Патоморфологические изменения за спонтанного отравления голубей диа- зиноном}

\author{
Р.С. Данкович, В.В. Туманов \\ dancor1802@i.ua
}

\begin{abstract}
Львовский национальный университет ветеринарной медицины и биотехнологий имени С.3. Гжицкого, ул. Пекарская, 50, г. Львов, 79010, Украина
\end{abstract}

\begin{abstract}
Фосфорорганические пестициды, в том числе диазинон, достаточно часто применяют для несанкиионированного отравления диких или домашних птиц. Гибель большого количества животных нередко становится предметом расследования по гражданским и уголовным делам. Для объективного установления диагноза в таких случаях необходимо провести комплексное патолого-анатомическое и химико-токсикологическое исследование. В статье описаны структурные изменения, развивающиеся в органах пищеварения, сердечно-сосудистой системы, дыхания, мочеиспускания, коже и иентральной нервной системе за спонтанного отравления голубей диазиноном. В ходе проведенного патолого-анатомического исследования выявили выраженные дисииркуляторные проиессы: застойную гиперемию (особенно в сосудах кожи в области шеи и вола), а также во внутренних органах, стазы, периваскулярные отеки и кровоизлияния. Также регистрировали альтеративные изменения (преимущественно белковую дистрофию и некрозы) гепатоциитов, кардиомицитов, нефрочитов и нейронов головного мозга. Выявленные изменения свидетельствуют о развитии необратимых альтернативных процессов в паренхиматозных элементах печени, почек, миокарда и головного мозга. При вскрытии отбирали материал (кормовые массы с вола) для проведения химико-токсикологического исследования. В результате проведения исследования экстракта
\end{abstract}

\section{Citation:}

Dankovych, R., Tumanov, V. (2016). Pathomorphological changes of spontaneous poisoning dove of diazinon. Scientific Messenger LNUVMBT named after S.Z. Gzhytskyj, 18, 3(70), 74-77. 
из содержимого вола птицы методом тонкослойной хроматографии на бумаге с проявлением йодвисмутовым реактивом получено качественную положительную реакцию по соединения диазинон.

Ключевые слова: фосфорорганические соединения, диазинон, пестициды, отравления, сизый голубь, патоморфология, застойная гиперемия, белковая дистрофия, некроз

\title{
Pathomorphological changes of spontaneous poisoning dove of diazinon
}

\author{
R. Dankovych, V.Tumanov \\ dancor1802@i.ua \\ Lviv national university of veterinary medicine and biotechnologies named after S. Gzhytskyj, \\ Pekarska Str., 50, Lviv, 79010, Ukraine
}

\begin{abstract}
Organophosphate pesticides, including diazinon, often used for illegal poisoning wild or domestic birds. The loss of a significant quantity of animals often become the subject of investigation in civil or criminal cases. For an objective diagnosis in such cases it is necessary to complete pathological-anatomical and chemical-toxicological studies. This article describes the structural changes that develop in the digestive system, cardiovascular system, respiratory, urinary, skin and central nervous system by spontaneous poisoning pigeons of diazinon. When conducted pathological-anatomical studies revealed pronounced dyscirculatory processes: congestive hyperemia (especially in the vessels of the skin in the neck and ox), and in the internal organs, stasis, perivascular edema and hemorrhage. Also registered alteration changes (protein degeneration and necrosis) of hepatocytes, cardiomyocytes, cells of nefron and neuron of cerebrum. Revealed changes suggest alternative development of irreversible processes in parenchymal cells of the liver, kidneys, myocardium and cerebrum. When autopsy selected material (feed the masses crop of birds) for chemicaltoxicological research. As a result the research the extract of selected content crop of birds by thin layer chromatography paper manifestation of iodine bismuth quality received positive reaction on the compound diazinon.
\end{abstract}

Key words: organophosphate, diazinon, pesticides, poisoning, rock dove, anatomical pathology, congestive hyperemia, degeneration, necrosis.

\section{Вступ}

На сьогоднішній день актуальною проблемою ветеринарної медицини є отруєння птахів фосфорорганічними пестицидами. Це насамперед пов'язано із широким використанням зазначених токсичних сполук у якості інсектицидів. Фосфорорганічні пестициди - це високоліпідотропні речовини, що легко проникають в організм через слизові оболонки органів травлення, дихання та непошкоджену шкіру, нагромаджуються в основному в печінці, головному мозку, м'язовій і жировій тканинах, нирках та інших органах. Виводяться метаболіти фосфорорганічних сполук з сечею, калом, молоком тощо. В основі їх токсичної дії лежить здатність блокувати фермент холінестеразу, наслідком чого є накопичення в тканинах медіатора ацетилхоліну, що призводить до порушення нервової провідності і тяжких розладів нервової трофіки (Cox, 2000; Zon, 2002; Debski et al., 2007; Pigolkin and Dubrovin, 2011; Botha et al., 2015).

Слід зазначити, що фосфорорганічні пестициди досить часто застосовують для несанкціонованого отруєння диких або свійських птахів, що нерідко стає предметом розслідування у різних цивільних або кримінальних справах. Комплексне вивчення структурних змін у таких випадках є міцним фундаментом та орієнтиром для подальших хімікотоксикологічних досліджень. У зв'язку з цим вивчення патоморфології отруєння птахів діазиноном $є$ актуальним питанням сучасної ветеринарної медицини і має науково-практичне значення (Zon, 2002; Botha et al., 2015).

\section{Матеріал і методи досліджень}

Дослідження проведено на сизих голубах (Columba livia), що загинули в місті Львові у серпні 2016 року (рис. 1). У зв'язку з цим було розпочато кримінальне провадження. Трупи голубів $(\mathrm{n}=21)$ надійшли на кафедру нормальної та патологічної морфології і судової ветеринарії Львівського національного університету ветеринарної медицини та біотехнологій ім. С.3. Гжицького для проведення судововетеринарної експертизи, з метою визначення причини їх загибелі. Розтин птахів проводили за методом Шора. Шматочки органів фіксували у 10\% нейтральному формаліні. Гістозрізи виготовляли за допомогою санного мікротома, фарбували гематоксилін-еозином (Mulish and Welsh, 2010). Також проводили хімікотоксикологічне дослідження екстракту вмістимого вола методом тонкошарової хроматографії на папері $з$ проявленням йодвісмутовим реактивом для визначення наявності у кормах діазинону (Filov, 1964).

\section{Результати та їх обговорення}

Під час зовнішнього огляду трупів голубів виявили виражену гостру застійну гіперемію шкіри у ділянці шиї та вола, а у дещо меншій мірі в ділянці підгрудка. Унаслідок цього шкіра у зазначених ділянках тіла забарвлюється у вишнево-червоний колір 3 ціанотичним відтінком (рис. 2). За гістологічного дослідження виявили різке розширення переважно венозних судин, периваскулярні набряки. Капіляри також розширені, кількість еритроцитів у них значна, відзначається склеювання еритроцитів. 


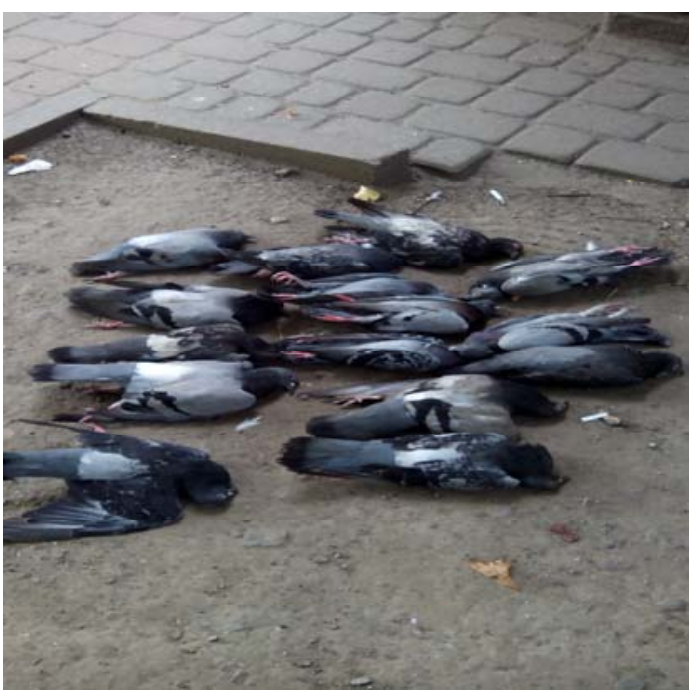

Рис. 1. Масова раптова загибель голубів

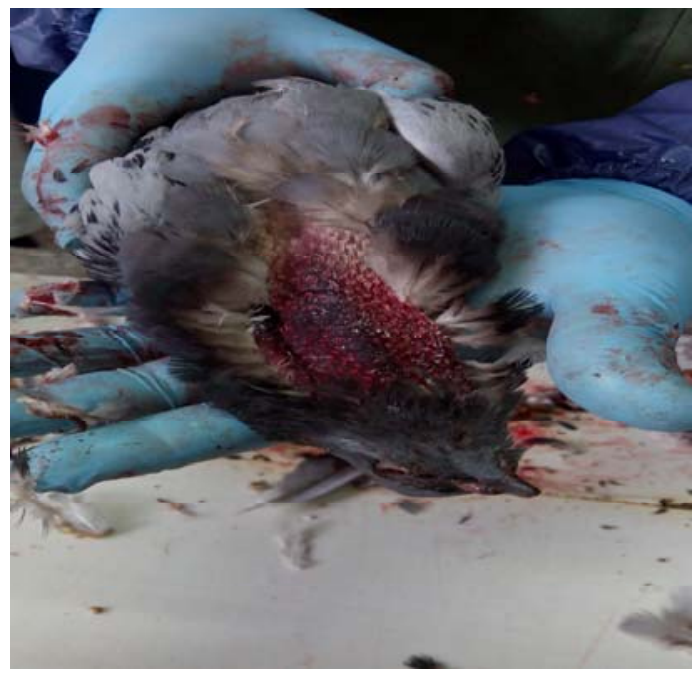

Рис. 2. Застійна гіперемія в ділянці шиї

У ротовій порожнині наявна незначна кількість кормів та слизу. Воло переповнене кормами. Слизова оболонка вола дещо набухла. У залозистому та м'язовому шлунку помірна кількість кормових мас. Слизова оболонка залозистого шлунка дещо набухла, на іiі поверхні виявили збільшену кількість слизу. Слизова оболонка тонких кишок незначно набухла, гіперемійована, на ії поверхні візуалізується незначно збільшена кількість слизу світло-сірого кольору.

Печінка збільшена, дряблої консистенції, нерівномірно забарвлена у коричнево-червоний колір, 3 поверхні розрізу стікає венозна кров. За гістологічного дослідження виявили переповнення внутрідолькових капілярів синусоїдного типу еритроцитами, крововиливи, незначну інфільтрацію строми макрофагами та лімфоцитами. Гепатоцити набухлі, у їх цитоплазмі візуалізуються дрібні вакуолі. Досить часто реєструються некротичні зміни гепатоцитів (рис. 3).

Нирки незначно збільшені, нерівномірно забарвлені у сіро-жовтий колір з вкрапленнями червоного кольору, дещо дряблої консистенції. Сечоводи помір- но наповнені сечею. За гістологічного дослідження виявили некротичні зміни епітеліоцитів ниркових канальців (рис. 4), що були найбільш вираженими у проксимальному сегменті нефрона. Окремі нефроцити або їх групи десквамуються у просвіт ниркових канальців. Дрібні венозні судини та капіляри перитубулярної сітки розширені, переповнені еритроцитами. Еритроцити у капілярах розташовуються у декілька рядів, склеюються. Подекуди трапляються перивазальні набряки та діапедезні крововиливи.

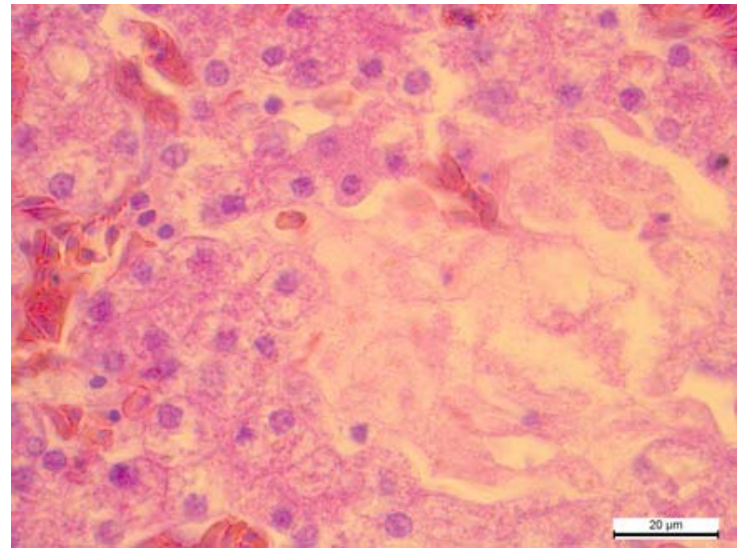

Рис. 3. Некротичні та дистрофічні зміни гепатоцитів.

Гематоксилін-еозин х 1000

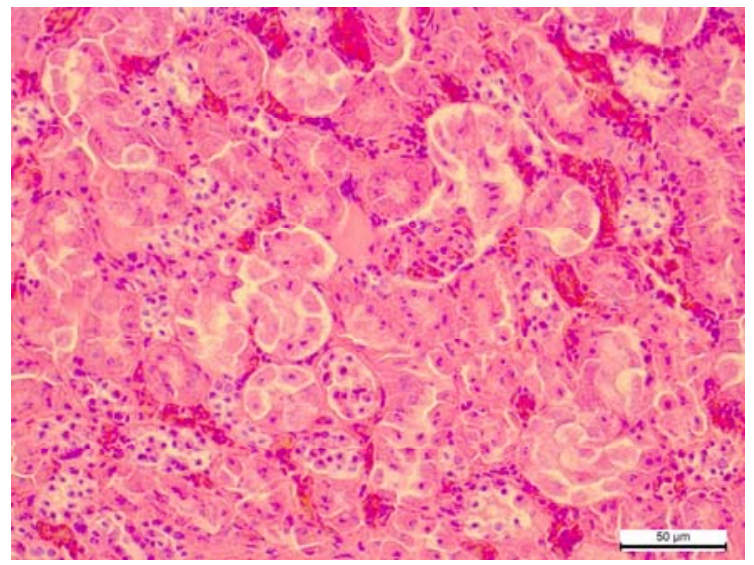

Рис. 4. Некротичні зміни нефроцитів. Гематоксилін-еозин х 400

Серцева сорочка гладка, блискуча, без нашарувань та крововиливів. Спостерігається помірне розширення правого передсердя та шлуночка та незначне потоншення їх стінки. Під епікардом в окремих тварин трапляються невеликі крапкові або плямисті крововиливи. Міокард нерівномірно забарвлений у червоносірий колір. Ендокард гладкий та блискучий. За гістологічного дослідження виявили, що окремі кардіоміоцити втрачають посмугованість, деякі з них зазнають некротичних змін. Судини міокарду розширені, переповнені еритроцитами. Строма міокарду подекуди інфітрована лімфоцитами.

За гістологічного дослідження головного мозку виявили розширення та переповнення кров'ю судин 
різного калібру (рис. 5, 6), периваскулярні набряки, вакуольну дистрофію нейронів, а також некротичні зміни окремих нервових клітин. Подекуди трапляються діапедезні крововиливи. Візуалізуються ділянки просякання основної речовини головного мозку транссудатом.

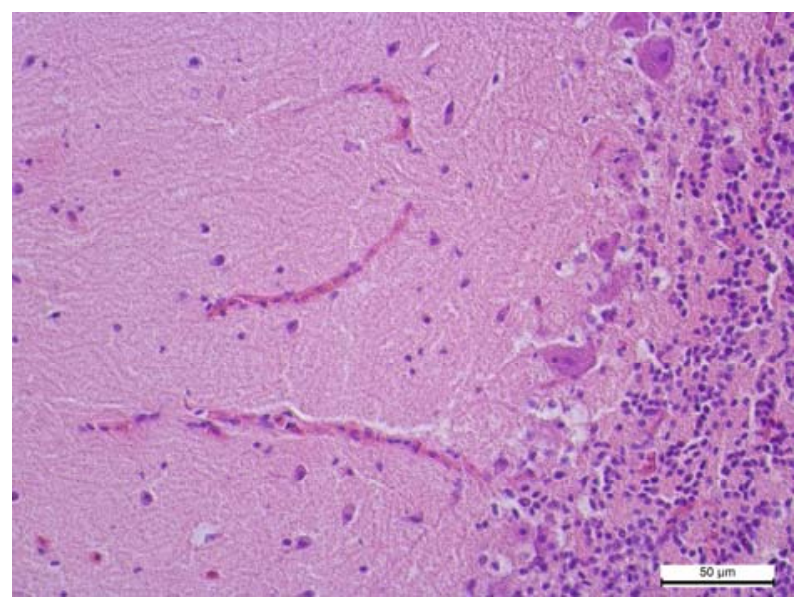

Рис. 5. Переповнення капілярів мозочка кров'ю. Альтеративні зміни нейронів. Гематоксилін-еозин х 400

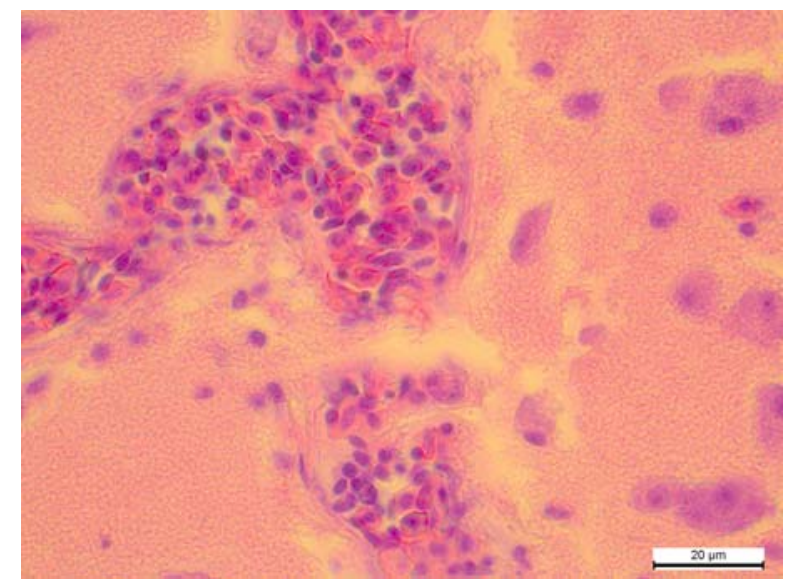

Рис. 6. Розширення та переповнення кров'ю судин головного мозку. Альтеративні зміни нейронів. Гематоксилін-еозин х 1000

Під час розтину відбирали матеріал (кормові маси 3 вола) для проведення токсикологічного дослідження. Унаслідок проведення токсикологічного дослі- дження екстракту з відібраного вмісту вола птиці методом тонкошарової хроматографії на папері $з$ проявленням йодвісмутовим реактивом отримано якісну позитивну реакцію щодо сполуки діазинон $[\mathrm{O}, \mathrm{O}-$ діетил-О-(2-ізопропіл-4-метилпіримідил6)тіофосфат]. Чутливість реакції 4 мкг $/ \mathrm{cm}^{2}$.

\section{Висновки}

Під час патологоанатомічного дослідження голубів, які загинули унаслідок отруєння діазиноном виявили виражені дисциркуляторні процеси у вигляді застійної гіперемії, стазів, периваскулярних набряків та крововиливів, а також альтеративні зміни (переважно вакуольну дистрофію та некрози) кардіоміцитів, гепатоцитів, нефроцитів та нейронів головного мозку тощо.

Перспективними напрямками подальших досліджень $\epsilon$ вивчення патогенезу уражень внутрішніх органів, центральної та периферичної нервової системи птахів за дії діазинону.

\section{Бібліографічні посилання}

Zon, G.A. (2002). Sudovo-veterynarna ekspertyza. Sumy: Mrija-1 (in Ukrainian).

Pigolkin, Ju.I., Dubrovin, I.A. (2011). Sudebnaja medicina. Compendium: uchebnoe posobie. M.: GJeOTAR-Media (in Russian).

Filov, V.A. (1964). Opredelenie jadohimikatov V biologicheskih substratah. Leningrad, Nauka (in Russian).

Botha, C., Coetser, H., Labuschagne, L. (2015). Confirmed organophosphorus and carbamate pesticide poisonings in South African wildlife (2009-2014). Journal of the South African Veterinary Association. 86(1), 1329-1335.

Debski, B., Kania, B., Kuryl, T. (2007). Transformations of diazinon, an organophophoshate compound in the environment and poisoning by this compound. Ekológia (Bratislava). 26(1), 68-82.

Cox, C. (2000). Diazinon: toxicology. Journal of pesticide reform. 20(2), 15-21.

Mulish, M., Welsh, U. (2010). Romeis. Mikroscopiche technic. Heidelberg. 127-154.

Стаття надійшла до редакияї 17.09.2016 